\title{
The efficacy of Ivabradine and Nebivolol in the Treatment of Stable Angina Pectoris Patients with Mild Left Ventricular Dysfunction
} Dr. Md. Rafiqul Islam*

\author{
Assistant Professor, Dept. of Cardiology, Kushtia Medical College, Kushtia, Bangladesh
}

DOI: $10.36347 /$ sjams.2020.v08i06.007

| Received: 10.05.2020 | Accepted: 18.05.2020 | Published: 11.06.2020

*Corresponding author: Dr. Md. Rafiqul Islam

Objective: In this study my main goal is to evaluate the efficacy of Ivabradine and Nebivolol in the Treatment of Stable Angina Pectoris Patients with Mild Left Ventricular Dysfunction. Methods: This cross-sectional observational study was done in tertiary medical college and hospital from December 2018 to December 2019.A total of 100 consecutive patients were included. The patients were evaluatedin 2 different groups $(1,2)$. In group-1 Nebivolol $5 \mathrm{mg}$ /daywas administered to the 50 patients included in GroupA. 50 patients were started onIvabradine $10 \mathrm{mg} / \mathrm{day}$ and these patients were includedinto group-2. Results: During the study, heart rate decreased (78 \pm 6$)$ to (65 \pm 5$)$ in Group: 1 and $(77 \pm 7)$ to $(70 \pm 5)$ in Group: 2.After 6 months' treatment LVEFfor the group-1 improved by $(48 \pm 6.5)$ to $(51 \pm$ $3.2)$, and forthe group-2 $(47 \pm 5.4)$ to $(51 \pm 2.3)$. There is no significant change in EF improvement in both groups.Dose-related sinus bradycardia occurred in (5\%) of the nebivolol-using patients included in Group-1, where as in group-2 it was $1 \%$. Conclusion: From my study I can conclude that, Ivabradine can be considered as first choice in patient with tachycardia induced angina as this agent for reducing heart rate as well as chest pain. The hypertensive patient with tachycardia may be treated by Nebivolol. Further study is needed better result.

Keywords: Coronary heart disease (CHD), Ivabradine, Nebivolol.

Copyright @ 2020: This is an open-access article distributed under the terms of the Creative Commons Attribution license which permits unrestricted use, distribution, and reproduction in any medium for non-commercial use (NonCommercial, or CC-BY-NC) provided the original author and source are credited.

\section{INTRODUCTION}

Atherosclerotic coronary artery disease is a chronicdisease. Acute coronary syndrome can trigger patientmortality. Recently coronary artery disease mortality hasdecreased significantly in many European countries.About $>80 \%$ of all coronary artery disease (CAD) deathsoccur in developing countries. SAP is a clinical conditionthat is frequently encountered with CAD. Newinvestigations are being developed for the diagnosis andprognosis of patients with SAP [1-3].

It has been shown thatmortality in chronic heart failure $(\mathrm{CHF})$ patient's mayincrease in relation to an elevated heart rate. With regardsto CHF mortality, it has been observed that an increasein heart rate of 1 beat per minute increases the mortalityrisk by $3 \%$, while an increase in heart rate of 5 beats perminute increases the mortality risk by $16 \%[4]$. Ivabradineinhibits the pacemaker If current by slowing the diastolicdepolarization slope in sinoatrial node cells in a dosedependent fashion. When the available data regarding ivabradine is examined, it can be seen that ivabradine hasthe potential to slow-down the development ofaterosclerosis, correct ischemia, and reduce thefrequency of angina attacks, the prevalence of fatal and non-fatal myocardial infarction, and the rate patient hospitalizationAmong the different betablockers, nebivolol is a cardio selective agent that has long-term efficacy[5].

In this study my main goal is to evaluate efficacy of Ivabradine and Nebivolol in the Treatment of Stable Angina Pectoris Patients with Mild Left Ventricular Dysfunction.

\section{OBJECTIVE}

General objective

- To evaluate efficacy of Ivabradine and Nebivolol in the Treatment of Stable Angina Pectoris Patients with Mild Left Ventricular Dysfunction

\section{Specific objective}

- To identify cardiovascular risk factors of the patients.

- To detect dose-related side effects of the patients. 


\section{Methodology}

\section{Study type}

- It was a cross sectional study.

\section{Place and period of the study}

- This study was carried out in tertiary medical college and hospital from December 2018 to December 2019.

\section{Method}

A total of 100 stable angina pectoris patients under follow-up in the cardiology department of tertiary medical college and hospital with LVEFs $45 \%$ to $50 \%$ were included into the study. The patients were evaluated in 2 different groups $(1,2)$. In group-1 Nebivolol $5 \mathrm{mg} /$ day was administered to the 50 patients included in Group A. 50 patients were started onIvabradine $10 \mathrm{mg}$ /day and these patients were includedinto group-2. All patients admitted in Cardiology department, fulfilling the inclusion criteria and exclusion criteria was considered for study. Informed written consent was taken from all patients before enrollment. Initial evaluation of the patients by history and clinical examination was performed and recorded in patients' data collection sheet. Demographic profile, and pulse, blood pressure, body weight was recorded.

\section{Statistical Analysis}

The numerical data obtained from the study was analyzed and significance of differences was estimated by using statistical methods. Computer based SPSS (Statistical Package for Social Science) was used. Data is expressed in percentage, frequencies, means and standard deviation as applicable by simple linear analysis, Pearson $\mathrm{x}^{2}$ square test, Students' $\mathrm{t}$ test, Pearson's correlation coefficient test, multivariate logistic regression analysis and Fisher's exact test as applicable. $\mathrm{P}$ value of less than 0.05 was considered as significant.

\section{RESULTS}

In figure-1 shows age distribution of the patients where in group- 1 most of the patients belong to 40-50 years age group where as in group-2 majority belong to $>50$ years age group. The following figure is given below in detail:

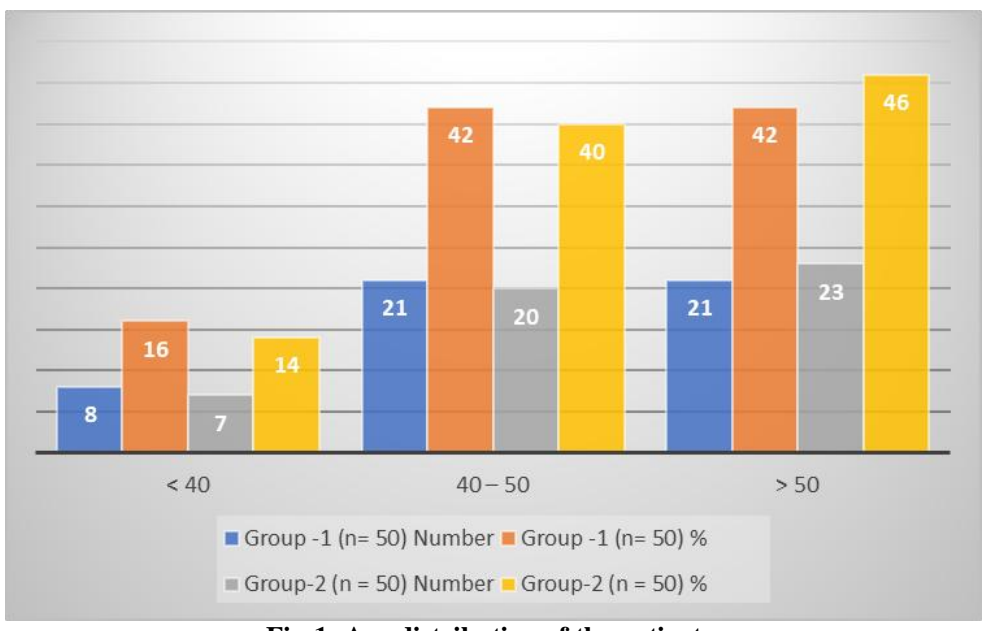

Fig-1: Age distribution of the patients.

In table-1 shows gender distribution of the patients where among the study population the male and female patients were identical in both the groups which was statistically insignificant $(p=0.74)$ by $\chi^{2}$ (Chi square) test. The following table is given below in detail:

Table-1: Gender distribution of the patients

\begin{tabular}{|l|l|l|l|l|l|}
\hline Gender & Group-1, n & Group-1, \% & Group-2, n & Group-2, \% & P value \\
\hline Male & 45 & 90.0 & 44 & 88.0 & \multirow{2}{*}{$0.74^{\text {ns }}$} \\
\cline { 1 - 5 } Female & 5 & 10.0 & 6 & 12.0 & \\
\hline
\end{tabular}

In table-2 shows distribution of the patients according to systolic Diastolic BP and heart rate where heart rate decreased $(78 \pm 6)$ to $(65 \pm 5)$ in Group: 1 and
(77 \pm 7$)$ to $(70 \pm 5)$ in Group: 2 . The following table is given below in detail: 


\begin{tabular}{|l|l|l|l|l|}
\hline Table-2: Distribution of the patients according to systolic Diastolic BPand heart rate \\
\hline & $\begin{array}{l}\text { Before treatment } \\
\text { Group -1 }(\mathbf{n = 5 0})\end{array}$ & $\begin{array}{l}\text { After treatment, } \\
\text { Group -1 }(\mathbf{n = 5 0})\end{array}$ & $\begin{array}{l}\text { Before } \\
\text { treatment, } \\
\text { Group-2 }(\mathbf{n = 5 0})\end{array}$ & $\begin{array}{l}\text { After treatment, } \\
\text { Group-2 }(\mathbf{n}=\mathbf{5 0})\end{array}$ \\
\hline Systolic BP $(\mathrm{mm} \mathrm{Hg})$ & $145 \pm 1.2$ & $125 \pm 2.1$ & $145 \pm 1.8$ & $130 \pm 2.4$ \\
\hline Diastolic BP $(9 \mathrm{~mm} \mathrm{Hg})$ & $90 \pm 2.5$ & $82 \pm 2.1$ & $89 \pm 2.2$ & $85 \pm 3.2$ \\
\hline Heart rate & $78 \pm 6$ & $65 \pm 5$ & $77 \pm 7$ & $70 \pm 5)$ \\
\hline
\end{tabular}

In figure-2 shows improvement of $\mathrm{EF}$ in Group-1 and Group-2 where after 6 months' treatment LVEF for the group-1 improved by $(48 \pm 6.5)$ to $(51 \pm$
$3.2)$, and forthe group $-2(47 \pm 5.4)$ to $(51 \pm 2.3)$. There is no significant change in EF improvement in both groups. The following figure is given below in detail:

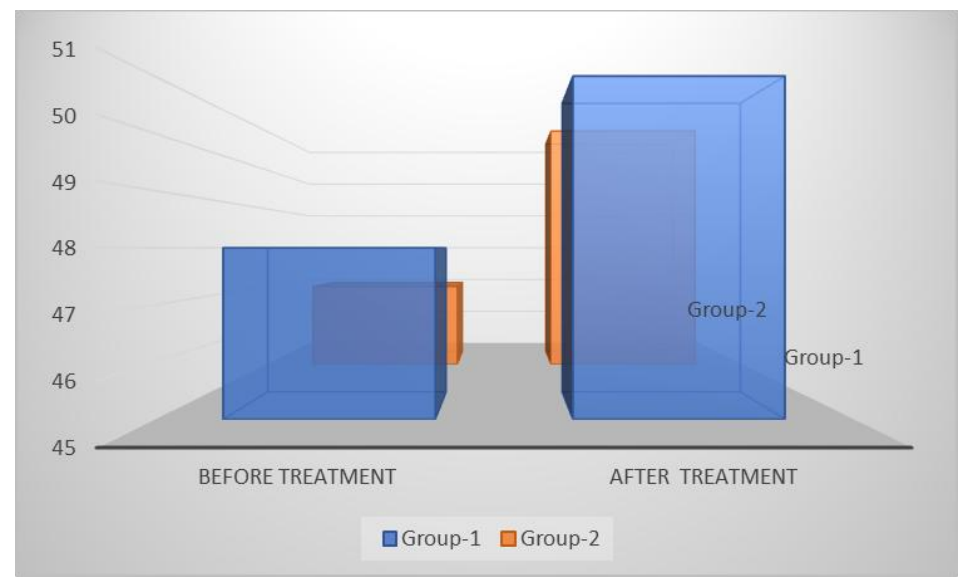

Fig-2: Improvement of EF in Group-1 and Group-2

In figure-3 shows dose-related side effects of the patients where dose-related sinus bradycardiaoccurred in (5\%) of the nebivolol-using patients included in Group-1, where as in group-2 it was $1 \%$. The following figure is given below in detail:

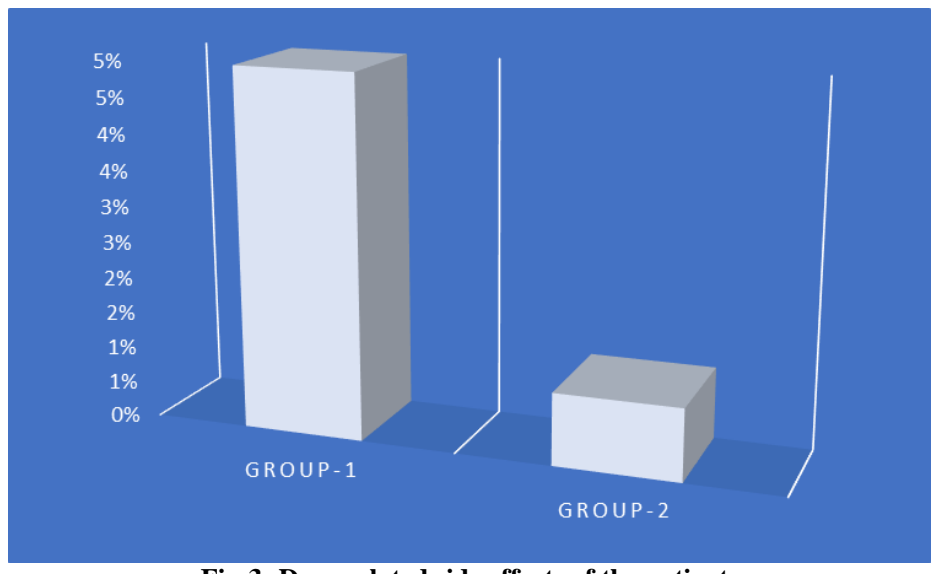

Fig-3: Dose-related side effects of the patients

\section{DISCUSSION}

In my study, I have compared the effects of ivabradineand nebivolol instable angina pectoris patients with mildLV systolic dysfunction (LVEF $\leq 50 \%$ ). No notabledifferences were observed in comparisons of nebivololand ivabradine monotherapies' efficacy on the LVEF (nebivolol - LVEF $48 \pm 6.5 \%$; ivabradine - LVEF $47 \pm 5.4$ ). In one study said that, Ivabradinewas reported as having no adverse effects on the LVEF [5].
The results of the one study have demonstratedthat ivabradine is a good choice for antianginal and antiischemic treatment, that it reduces the incidence ofmyocardial infarction and the need for coronary revascularization, and that it has a good tolerabilityprofile when used in combination with other drugs. Thisstudy has also shown that ivabradine use representsadvancement in the treatment of stable angina pectorispatients with heart rates of $\geq 70$ beats per minute, andthat the isolated decrease in heart rate caused byivabradine decreased the occurrence of coronary events even in patients already receiving 
optimal cardiovascularprotective therapies [6]. In their efficacy study on ivabradine and nebivolol combination therapy performed with 92patients, they observed no differencebetween these two drugs with regards to antianginal, antiischemic and antitachycardia efficacy [7]. The resultsof this study is in parallel with the above-mentionedstudies.

In my study, the effects of the ivabradine andnebivolol mono therapies on the respiratory system were evaluated. According to my study's results, ivabradinehas not demonstrated any effect that might lead topulmonary dysfunction. It has been shown that ivabradinehad no adverse effect on the pulmonary functions ofpatients with COPD and pulmonary hypertension in astudy[6].

I observed that nebivolol had minimal effect onpulmonary dysfunction. The effects of the ivabradine andnebivolol mono therapies on diastolic dysfunction wereevaluated in my patients. During the pre-treatment andthe six month treatment periods, ivabradine's efficacyon the diastolic parameters was found to be equal to thatof nebivolol. One study has conducted on 111patients with EFs below 50\% described ivabradine'seffect in improving diastolic parameters on its own [7].

\section{CONCLUSION}

From my study I can conclude that, Ivabradine can be considered as first choice in patient with tachycardia induced angina as this agent for reducing heart rate as well as chest pain. The hypertensive patient with tachycardia may be treated by Nebivolol. Further study is needed better result.

\section{REFERENCES}

1. Borer JS, Böhm M, Ford I, Komajda M, Tavazzi L, Sendon JL, Alings M, Lopez-de-Sa E, Swedberg K, Shift Investigators. Effect of ivabradine on recurrent hospitalization for worsening heart failure in patients with chronic systolic heart failure: the SHIFT Study. European heart journal. 2012 Nov 1;33(22):2813-20.

2. Swedberg K, Komajda M, Böhm M, Borer JS, Ford I, Dubost-Brama A, Lerebours G, Tavazzi L, SHIFT investigators. Ivabradine and outcomes in chronic heart failure (SHIFT): a randomised placebo-controlled study. The Lancet. 2010 Sep 11;376(9744):875-85.

3. Fox K, Ford I, Steg PG, Tendera M, Ferrari R, Beautiful Investigators. Ivabradine for patients with stable coronary artery disease and left-ventricular systolic dysfunction (BEAUTIFUL): a randomised, double-blind, placebo-controlled trial. The Lancet. 2008 Sep 6;372(9641):807-16.

4. Tatarchenko IP, Pozdniakova NV, Biriuchenko MV, Kapelovich V, Sekerko SA, Kupaeva RA. Clinical efficacy of ivabradin and nebivolol addition in combined treatment of ischemic heart disease patients with left ventricular dysfunction. Terapevticheskii arkhiv. 2008;80(9):40-4.

5. Tardif JC, Ponikowski P, Kahan T. Efficacy of the I f current inhibitor ivabradine in patients with chronic stable angina receiving beta-blocker therapy: a 4-month, randomized, placebocontrolled trial. European heart journal. 2009 Mar 1;30(5):540-8.

6. Akhmetzianova É, Gaĭnitdinova VV, Bakirov AB, Bogoroditskaia OA, Timershina IR. Effect of ivabradine on pulmonary hypertension in chronic obstructive pulmonary disease. Kardiologiia. 2012;52(2):41-6.

7. De Luca GÝ. diastolic heart failure. Am Coll Cardiol. 2012; 59: E1009. Fox K, Garcia MA, Ardissino D. Guidelines on the management of stable angina pectoris: Executive summary: The task force on the management of stable angina pectoris of the European Society of Cardiology. Eur Heart J. 2006;27:1341-81. 